4. Ofitsiynyy sayt UNWTO [Official site of UNWTO]. Retrieved from: https://www.e-unwto.org/doi/pdf/10.18111/9789284421152 [in Ukraine].

5. Fedorchenko, V. Kyiv, Fomenko, N. A., Skrypnyk, M.I., Tsekhmistrovoyi, H.S. (2004) Pedahohika turyzmu: navchal'nyy posibnyk dlya VNZ [Tourism pedagogy: a textbook for universities]. K.: Vydavnychyy Dim „Slovo” [in Ukraine].

6. Pro vyshchu osvitu: Zakon Ukrayiny vid 01.07.2014 № 1556-VII [On Higher Education: Law of Ukraine]. VR Ukrayiny. Retrieved from: https://zakon.rada.gov.ua/laws/show/1556-18\#n504 [in Ukraine].

\title{
Fedorchenko V. K. The actual problems of continuous learning in tourism education
}

This paper is to consider the features of tourism sphere and tourism education, especially such characteristics as: decentralisation, cultural and ethnic heterogeneity and the place of students in educational system. Specific attention is considered to the three basic principles of higher education realisation (accessibility, equal possibilities, included diversity). The specificity of professional activity in tourism sector was analyzed and its connection with tourism professional training wasstudied.

The article analyzes the formation and structural components, the solution of priority and perspective strategic issues created in Ukraine and approved by the Verkhovna Rada of Ukraine legislation in the field of tourism education. The formation and stages of development of tourist education in Ukraine and in other European countries are analyzed. The scientific works on the problems of tourism and hotel and restaurant business have been elaborated and on this basis the conclusions are drawn for the use of the aforementioned experience in the scientific, educational and practical field of this field. Attention is drawn to the expansion of additional services, development and formation of currency-intensive services in order to significantly increase revenues to the state budget. The attention is paid to the special role of the state in facilitating and consolidating the efforts of different directions of economic activity in the country. Issues concerning the implementation of decisions of the Hague Declaration on Tourism are introduced into the daily practice, as well as the introduction of units on tourism and hotel issues by the Ministries and departments of the country into the planning system of tourism development issues.

Key words: tourism sphere, tourism professional education, equal possibilities, diversity, accessibility, tourism, industry best practices.

УДК 378.147:811.161.2

DOI https://doi.org/10.31392/NPU-nc.series5.2020.72-2.50

Фоменко Т. М.

\section{ШЛЯХИ АКТИВІЗАЦІї ПІЗНАВАЛЬНОЇ ДІЯЛЬНОСТІ ІНОЗЕМНИХ СТУДЕНТІВ ПІД ЧАС ВИВЧЕННЯ УКРАЇНСЬКОЇ МОВИ}

Розглядається проблема активізації пізнавальної діяльності іноземних студентів на заняттях украӥнської мови. Зазначається, щчо основна діяльність викладача украӥнської мови як іноземної полягає не лише в організації процесу навчання, але й також в організаџї самостійної пізнавальної діяльності студентів, формуванні творчого мислення, розвитку їхнього потенціалу. Ключовим питанням викладання украӥнської мови як іноземної є пошук ефективних методів навчання, які б сприяли стійкому засвоєнню нових знань і вмінню вільно оперувати мовним матеріалом.

3'ясовано, щчо розвитку активності та зацікавленості іноземних студентів у процесі вивчення украӥнської мови сприяє використання інтерактивних технологій. Наголошується, щяо інтерактивні технології підвищують результативність навчального процесу, створюють комфортні умови для навчання, урізноманітнюють освітній процес, зацікавлюють і мотивують студентів. Виокремлено основні інтерактивні технології, які необхідно впроваджувати, щзоб досягти ефективних результатів під час вивчення украӥнської мови як іноземної. Охарактеризовано дидактичні можливості рольових ігор, методу проектів, мультимедійних технологій.

У результаті дослідження встановлено, щзо використання рольових ігор сприяє активізації пізнавальної діяльності студентів, підвищенню інтересу тощо. Участь у проектній роботі сприяє набуттю таких умінь і навичок, як пошук, виокремлення, аналіз, структурування необхідної інформацїі; уміння інтегрувати інформацію з різних галузей знань. Використання інтернет-технологій у поєднанні з методом проекту дозволяє студентам на практииі застосовувати свої знання, навички та уміння. Запровадження систем мультимедіа в прочесі вивчення украӥнської мови як іноземної забезпечує організацію самостійної навчальної діяльності, сприяє підвищенню мотивації. Залучення мультимедійних технологій у навчальний процес поліпшує якість презентації навчального матеріалу та ефективність його засвоєння студентами, збагачує зміст освітнього прочесу, підвищує мотивацію до вивчення украйнської мови.

Ключові слова: навчально-пізнавальна діяльність, пізнавальний інтерес, іноземні студенти, украӥнська мова як іноземна, інтерактивні технології.

Останнім часом спостерігається зростання попиту на вивчення української мови серед іноземних громадян. Все більше іноземних студентів бажають опанувати українську мову, яка буде необхідною для їхнього подальшого навчання. Безперечно, викладання української мови є важливим аспектом підготовки іноземних студентів, метою вивчення якої є формування комунікативної компетентності, що дасть їм можливість 
задовольнити комунікативні потреби у ситуаціях щоденного спілкування, допоможе адаптуватися в іншомовному середовищі.

Предметом дослідження вітчизняних науковців були різні аспекти проблеми навчання іноземних студентів української мови: організація самостійної роботи студентів-іноземців (Т. Лещенко, І. Самойленко), навчання говорінню іноземців (А. Чистякова), міжкультурна комунікація у процесі викладання української мови як іноземної (Н. Кравцова), навчання аудіюванню (Л. Богуславська, Л. Сеник, Г. Філатова), використання інтерактивних методів у дистанційному навчанні української мови як іноземної (В. Ногай), ігрові технології в навчанні української мови як іноземної (О. Палінська, Г. Швець) та ін.

Незважаючи на численні здобутки, питання активізації пізнавальної діяльності студентів залишається однією з найбільш актуальних проблем сучасної педагогічної науки й практики. Реалізація принципу активності у навчанні має певне значення, оскільки навчанню притаманний діяльнісний характер; від якості навчання як діяльності залежить результат навчання та розвитку студентів.

Мета статті полягає у визначенні шляхів активізації пізнавальної діяльності іноземних студентів у процесі вивчення української мови.

Ключовим питанням викладання української мови як іноземної є пошук ефективних методів навчання, які б сприяли розумінню, стійкому засвоєнню нових знань і вмінню вільно оперувати мовним матеріалом. Сьогодні основна діяльність викладача полягає не лише у вмілій організації процесу навчання, але й також в організації самостійної пізнавальної діяльності студентів, формуванні творчого мислення, розвитку їхнього потенціалу. Перед викладачем постає питання: яким шляхом можна активізувати пізнавальну діяльність студентів на практичних заняттях української мови як іноземної? Першочерговим завданням у цьому напрямку є створення певних умов для продуктивної діяльності й творчості студентів.

На наш погляд, навчальна діяльність буде більш успішною за двох важливих умов, що сприяють активізації діяльності іноземних студентів під час вивчення української мови. По-перше, студенти проникають у сутність досліджуваних фактів і явищ, якщо виявляють пізнавальну самостійність. По-друге, якість засвоєння знань залежить від ступеня активності, що зростає при підвищенні рівня самостійної роботи.

Розвитку пізнавального інтересу студентів, відповідно до погляду Г. Щукіної [9], сприяє:

1) відбір змісту навчального матеріалу - знайомство студентів із новими фактами; наведення нових порівнянь; застосування нових форм діяльності, нових способів вирішення завдань; актуалізація значущості знань для майбутньої професійної діяльності;

2) організація навчальної діяльності - самостійна робота, пов'язана із набуттям нових способів пізнавальної діяльності; організація проблемної ситуації; дослідницький підхід; творча робота (повідомлення та доповіді);

3) стосунки, які складаються в навчальному процесі між студентами, а також між ними й викладачем, позитивний емоційний фон навчального процесу.

Зазначимо, що в процесі вивчення української мови як іноземної важливо, щоб зміст навчального матеріалу був зрозумілим, відповідав інтересам і професійним потребам іноземних студентів, викликав у них позитивні емоції.

Основу для активізації пізнавальної діяльності студентів, на думку дослідників, створюють такі чинники, як-от: навчальний зміст; методи й прийоми навчання; форми організації навчання [8, с. 74]. Саме ці зовнішні стимули впливають на пізнавальну активність через її внутрішні джерела.

Для того, щоб цілеспрямовано розвивати мотивацію іноземних студентів у процесі вивчення української мови, потрібно використовувати найбільш результативні прийоми організації їхньої навчальної діяльності; створювати засади для розвитку навчального інтересу, творчої активності.

Спираючись на основні положення педагогічних праць дослідників [8; 9], визначимо такі напрями стимулювання мотивів, потреб, інтересу до навчально-пізнавальної діяльності студентів: забезпечення професійного спрямування змісту дисципліни; збільшення частки колективної та самостійної роботи студентів; удосконалення різноманітних форм, методів, прийомів, засобів навчання; надання переваги нетрадиційним формам організації занять; створення позитивної атмосфери в процесі навчальної діяльності.

Ефективність навчання української мови як іноземної залежить від прийомів, методів, форм навчальної роботи, що обираються викладачем. Відповідно, розвиваюча роль цих прийомів, методів і форм залежить від того, наскільки вони активізують думку іноземних студентів, спонукають їх до самостійних дій, узагальнень, висновків, а також наскільки успішно сприяють формуванню здатності до переробки, систематизації, освоєння різноманітної інформації.

Серед методів мотивації навчально-пізнавальної діяльності Ю. Бабанський виокремлює методи формування пізнавальних інтересів [1]. Методи формування пізнавального інтересу - це, перш за все, методи активізації навчально-пізнавальної діяльності. Такі методи забезпечують найважливіші функції регулювання навчальної діяльності студентів, їх пізнавальної, вольової та емоційної активізації. Так, найефективнішими методами формування пізнавального інтересу іноземних студентів (відповідно до Ю. Бабанського [1], А. Маклакова [2], С. Рубінштейна [7], Г. Щукіної [9] та ін.) є: рольові та ділові ігри, метод створення ситуації новизни навчального матеріалу, метод опори на здобутий життєвий досвід тощо. 
Однією із можливостей вирішення проблеми пошуку шляхів підвищення пізнавального інтересу студентів до вивчення української мови як іноземної вважаємо використання інноваційних технологій у навчанні.

Застосування на практиці інноваційних методологічних підходів, таких, як: інтерактивні методи викладання та використання технічних засобів навчання (комп’ютерних і мультимедійних, мережі Інтернет) для контролю знань, зберігання та використання навчальних матеріалів, дозволяє викладачам впроваджувати й удосконалювати нові методи роботи, підвищувати ефективність навчального процесу і рівень знань студентів.

Серед різноманітних методів і прийомів навчання чільне місце посідають інтерактивні методи навчання, оскільки суттєво підвищують результативність навчального процесу. Вони створюють комфортні умови для навчання, урізноманітнюють освітній процес, зацікавлюють і мотивують студентів. Завдяки використанню інтерактивних методів суттєво покращується ефективність навчання, адже студенти значно краще засвоюють та запам’ятовують нові знання, здатні застосувати їх на практиці.

До інтерактивних методів навчання відносять: робота в малих групах, дискусії та дебати, «мозкові штурми», кейс-метод, метод проектів, ігрові комунікативні вправи тощо. Особливістю використання цих методів є те, що в навчальний процес залучаються всі його учасники - і викладач, і студенти; на занятті панує атмосфера взаємодопомоги та кооперації, де кожен робить свій індивідуальний внесок, ділиться знаннями, ідеями, досвідом.

Для залучення студентів до процесу навчання, розвитку пізнавальної активності, підвищення інтересу доцільним є використання на заняттях рольових ігор. Саме ігрові прийоми навчання створюють «живі» ситуації спілкування. Гра дозволяє поетапну обробку в процесі ігрової взаємодії нових способів орієнтування студентів в життєвих ситуаціях. Під час гри змінюється пасивна позиція студента на свідомо активну, зростає пізнавальна активність студентів, що дає їм можливість отримувати й засвоювати велику кількість інформації.

Виокремлюють чотири функції гри: засіб розвитку мотиваційно-потребнісної сфери, засіб пізнання, засіб розвитку розумових дій і засіб розвитку довільної поведінки [10].

Перевага рольових ігор полягає в тому, що в даних типах вправ мовленнєва діяльність розглядається в соціальному контексті, тобто враховується тема розмови, стосунки між партнерами по спілкуванню тощо, що сприяє наближенню навчання до реального життя. Саме в грі студенти засвоюють норми поведінки. Беручи участь у рольовій грі, студенти отримують можливість застосувати свої знання в реальному житті.

У процесі створення рольової гри викладач має враховувати потреби студентів і підбирати такі ігрові ситуації, участь у яких допоможе іноземним студентам набути навичок невимушеного міжособистісного спілкування. Студентам пропонується взяти участь у моделюванні різних життєвих ситуацій. Тематикою рольових ігор можуть бути «У магазині», «У кафе», «У лікаря», «У транспорті», «Пересування містом» тощо.

Використання рольових ігор сприяє розвитку монологічного й діалогічного мовлення та здатне розв'язати певні мовні проблеми: знання відповідної лексики, термінології, засвоєння максимального обсягу мовленнєвих моделей, вміння грамотно висловлювати свої думки відповідно до мовних норм [4, с. 51]. Гра, що містить проблемні питання й тим самим зачіпає особистісні інтереси студентів, спонукає їх до висловлювання власної думки. Гра завжди передбачає прийняття рішення - як вчинити, що сказати, як відреагувати. Це загострює розумову діяльність студентів. Таким чином, використання рольової гри з урахуванням вищеназваних ознак сприяє активізації навчальної діяльності студентів.

Проведення рольових ігор дозволяють сформувати вміння та навички прийняття грамотних рішень в майбутньому в процесі професійної діяльності, сприяють кращому засвоєнню студентами навчального матеріалу 3 предмета. Допомагаючи знайти конкретні варіанти вирішення проблем, інтерактивні форми навчання сприяють рольового розвитку учасників, навчаючи їх співпраці, комунікації і роботі в колективі.

Метод прооектів. Технологія навчання із застосуванням методу проектів грунтується на залученні студентів до активної пізнавальної діяльності. Як зазначає дослідниця Є. Полат [5], метод проектів дозволяє інтегрувати знання 3 різних галузей при вирішенні однієї проблеми. Серед загальнодидактичних вимог щодо ефективного використання методу проектів учена виокремлює наявність актуальної проблеми (або завдання), що вимагає дослідницький пошук для ії вирішення (наприклад, дослідження історії виникнення різноманітних свят або традицій харчування тощо).

Метод проектів сприяє формуванню в студентів таких особистісних якостей, які засвоюються лише в діяльності. Так, беручи участь у проектній роботі в процесі вивчення української мови, іноземні студенти набувають таких умінь і навичок, як-от: пошук, виокремлення, аналіз, структурування необхідної інформації; уміння інтегрувати інформацію з різних галузей знань. Результатами такої діяльності можуть бути проекти «Моя сім’я», «Рідне місто», «Визначні місця України», «Моє навчання в Україні» тощо.

Студенти залучаються до проектної діяльності, виконання навчальних проектів із використанням інтернет-ресурсів. У роботі з інтернет-ресурсами змінюється і роль викладача, основне завдання якого підтримувати й спрямовувати розвиток особистості студентів, їхній творчий пошук у процесі проектної діяльності. Стосунки зі студентами будуються на принципах співробітництва та спільної діяльності. Так, у проектній діяльності яскраво проявляється співтворчість викладача й студента, взаємна зацікавленість у спільному успіху - це надає широкі можливості для самоствердження, самостійного вибору не лише змісту, але й засобів виконання навчальних проектів. 
Інтернет-технології можуть успішно використовуватись на заняттях із метою пошуку студентами додаткової інформації з теми, що вивчається, для збору даних для створення мультимедійної презентації в програмі Power Point. Запровадження систем мультимедіа в процесі вивчення української мови як іноземної забезпечує реалізацію активних форм і методів навчання, організацію самостійної навчальної діяльності, сприяє підвищенню мотивації за рахунок можливості використання сучасних засобів комплексної аудіовізуальної інформації, підвищенню емоційного сприйняття інформації [6, с. 114]. Графіка, анімація, фото, відео, звук, текст в інтерактивному режимі роботи створюють інтегроване інформаційне середовище.

Мультимедійні технології навчання об’єднують у собі традиційну статичну візуальну інформацію (текст, графіку) і динамічну інформацію (вимову, музику, відео, анімацію), що зумовлює одночасний вплив на зорову і слухову пам'ять іноземних студентів. Залучення зазначених технологій у навчальний процес поліпшує якість презентації навчального матеріалу та ефективність його засвоєння студентами, збагачує зміст освітнього процесу, підвищує мотивацію до вивчення української мови.

До основних переваг застосування мультимедійних технологій у вищій освіті як виду інформаційнокомунікаційних технологій навчання порівняно із традиційними засобами передавання інформації та засобами навчання відносять: можливість поєднання логічного й образного способів опанування інформації; активізація освітнього процесу за рахунок посилення наочності; інтерактивна взаємодія, спілкування в інформаційно-освітньому просторі [3, с. 27].

Серед мультимедійних засобів виокремлюють: електронні підручники, словники, енциклопедії; презентації; аудіо- та відеоматеріали тощо.

Наприклад, мультимедійні презентації доцільно використовувати при введенні лексичного, граматичного, країнознавчого матеріалу, як опори при навчанні монологічного та діалогічного мовлення. Застосування презентацій сприяє кращому засвоєнню навчального матеріалу; завдяки використанню анімації з'являються можливості виокремлення найбільш значущих елементів за допомогою кольору, шрифту, додавання фотографій тощо.

За допомогою інтернет-технологій іноземні студенти створюють проекти, мультимедійні презентації. Використання інтернет-технологій у поєднанні з методом проекту дозволяє студентам на практиці застосовувати свої знання, навички та уміння, тому і є однією з форм дослідницької та пізнавальної діяльності.

Висновки. Таким чином, використання таких інтерактивних технологій, як рольові ігри, метод проектів, мультимедійні презентації сприяє активізації пізнавальної діяльності іноземних студентів у процесі вивчення української мови.

\section{Використана література:}

1. Бабанский Ю. К. Рациональная организация учебной деятельности. Москва : Знание, 1981. 96 с.

2. Маклаков А. Г. Общая психология. Санкт-Петербург: Питер, 1999. 720 с.

3. Мультимедійні системи як засоби інтерактивного навчання: посіб. / М. І. Жалдак та ін. / за ред. Ю. О. Жука. Київ : Педагогічна думка, 2012. $112 \mathrm{c}$.

4. Палінська О. Рольові ігри на заняттях з української мови як іноземної. Теорія і практика викладання української мови як іноземної. 2015. Вип. 11. С. 50-56.

5. Полат Е. С. Метод проектов на уроках иностранного языка. Иностранные языки в школе. 2000. № № 2, 3.

6. Роберт И. В. Современные информационные технологии в образовании: дидактические проблемы; перспективы использования. Москва : ИИО РАО, 2010. 140 с.

7. Рубинштейн С. Л. Основы общей психологии. Санкт-Петербург: Питер, 2002. 712 с.

8. Шамова Т. И. Активизация учения школьников. Москва : Педагогика, 1982. 209 с.

9. Щукина Г. И. Педагогические проблемы формирования познавательных интересов учащихся. Москва : Педагогика, 1986.208 с.

10. Эльконин Д. Б. Психология игры. 2-е изд. Москва : Гуманит. изд. центр ВЛАДОС, 1999. 360 с.

\section{References:}

1. Babanskiy Yu.K. (1981) Ratsionalnaya organizatsiya uchebnoy deyatelnosti [Rational organization of educational activity]. Moskva: Znanie. 96 s. [in Russian]

2. Maklakov A.G. (1999) Obschaya psihologiya [General psychology]. Sankt-Peterburg: Piter. 720 s. [in Russian]

3. Multymediini systemy yak zasoby interaktyvnoho navchannia: posib. [Multimedia systems as an online learning tool: a guide] (2012) / M.I. Zhaldak ta in. / za red. Yu.O. Zhuka. Kyiv : Pedahohichna dumka. 112 s. [in Ukrainian]

4. Palinska O. (2015) Rolovi ihry na zaniattiakh z ukrainskoi movy yak inozemnoi [Role-playing games at the Ukrainian language as a foreign language]. Teoriia i praktyka vykladannia ukrainskoi movy yak inozemnoi. Vyp. 11. S. 50-56. [in Ukrainian]

5. Polat E.S. (2000) Metod proektov na urokah inostrannogo yazyika [Method of projects at foreign language lessons]. Inostrannyie yazyiki v shkole. № 2, 3. [in Russian]

6. Robert I.V. (2010) Sovremennyie informatsionnyie tehnologii v obrazovanii: didakticheskie problemyi; perspektivyi ispolzovaniya [Modern information technologies in education: didactic problems; prospects for use]. Moskva: RAO. $140 \mathrm{~s}$. [in Russian]

7. Rubinshteyn S.L. (2002) Osnovyi obschey psihologii [Fundamentals of General Psychology]. Sankt-Peterburg: Piter, 2002.712 s. [in Russian]

8. Shamova T.I. (1982) Aktivizatsiya ucheniya shkolnikov [Activization of schoolchildren' learning]. Moskva: Pedagogika, 1982. 209 s. [in Russian]

9. Schukina G.I. (1986) Pedagogicheskie problemyi formirovaniya poznavatelnyih interesov uchaschihsya [Pedagogical problems of the formation of cognitive interests of students]. Moskva: Pedagogika. 208 s. [in Russian]

10. Elkonin D.B. (1999) Psihologiya igryi [Pedagogical problems of the formation of cognitive interests of students]. 2-e izd. Moskva: Gumanit. izd. tsentr VLADOS. 360 s. [in Russian] 
Fomenko T. The ways of activation of international students' cognitive activity in the process of the Ukrainian language study

The article deals with the problem of activation of international students' cognitive activity at the Ukrainian language classes. It is noted that the main task of the teacher of Ukrainian as a foreign language is not only to organize the learning process, but also to organize the independent cognitive activity of students, to form creative thinking, to develop their potential. The key issue of teaching Ukrainian as a foreign language is finding effective teaching methods that would facilitate the sustainable acquisition of new knowledge and the ability to freely operate the language material.

It was found out that the development of activity and interest of international students in the process of learning Ukrainian language promotes the use of interactive technologies. It is emphasized that interactive technologies increase the effectiveness of the educational process, create comfortable conditions for learning, diversify the educational process, interest and motivate students. The main interactive technologies that need to be implemented in order to achieve effective results in the process of studying Ukrainian as a foreign language are highlighted. Didactic possibilities of role-playing games, method of projects, multimedia technologies are characterized.

As a research result it is noted that the use of role-playing games promotes students' cognitive activity, increased interest, etc. Participation in the project work facilitates the acquisition of skills such as searching, highlighting, analyzing, structuring the necessary information; ability to integrate information from different fields of knowledge. The use of Internet technologies in conjunction with the project method allows students to apply their knowledge, skills and abilities in practice. Implementation of multimedia systems in the process of learning the Ukrainian as a foreign language provides the organization of independent educational activities, promotes motivation. The involvement of multimedia technologies in the educational process improves the quality of presentation of the educational material and the efficiency of its assimilation by students, enriches the content of the educational process, increases the motivation to learn Ukrainian.

Key words: educational and cognitive activity, cognitive interest, international students, Ukrainian as a foreign language, interactive technologies.

УДК 37.091.5-044.247:796

DOI https://doi.org/10.31392/NPU-nc.series5.2020.72-2.51

Халайджі С. В., Кананихіна О. М., Сергєєва Т. П., Яготін Р. С.

\section{ПЕДАГОГІЧНІ УМОВИ ФОРМУВАННЯ КУЛЬТУРИ ЗДОРОВ'ЯЗБЕРЕЖЕННЯ МАЙБУТНІХ ФАХІВЦІВ НА ЗАСАДАХ МІЖДИСЦИПЛІНАРНОЇ ІНТЕГРАЦІЇ}

Статтю присвячено проблемі виявлення, теоретичного обтрунтування та експериментальній перевіриі педагогічних умов формування культури здоров'язбереження майбутніх фахівців на засадах міждисциплінарної інтеграції. У статті розкривається значення поняття «культура здоров'язбереження», «міжсисииплінарна інтеграція».

Здійснено теоретичний аналіз наукових робіт для узагальнення різних поглядів учених на означену проблему, визначення теоретичних засад $і$ з'ясування базових понять дослідження.

У статті містяться результати сформованості культури здоров'язбереження майбутніх фахівців харчової промисловості на засадах міждисииплінарної інтеграчії на етапах вхідного і підсумкового.

Узагальнюючи результати наукових досліджень, визначено провідні компоненти ияього феномену, критерії і показники ї̈ вияву та рівні сформованості (високий, достатній, задовільний, низький).

Конкретизовано компоненти культури здоров'язбереження майбутніх фахівиів: мотиваиійно-світоглядний, когнітивно-змістовий, діяльнісно-операційний, регулятивно-рефлексивний, їх критерії оцінювання.

Визначено суттєву роль у формуванні культури здоров'язбереження майбутніх фахівців на засадах міждисииплінарної інтеграчії педагогічних підходів (системний, особистісний та аксіологічний підходи). Визначено та обтрунтовано педагогічні умови формування культури здоров'язбереження майбутніх фахівиів на засадах міждисциплінарноі інтеграиії: забезпечення мотивачії майбутніх фахівиів на здоров'язбереження як світоглядного орієнтиру; використання методів міждисииплінарної інтеграиії в професійній підготовиі студентів з метою поглиблення їхніх знань про здоров'я; розширення навичокщчодо ведення здорового способужсиття; організачія самостійноїздоров 'язбережувальної діяльності студентів.

Удосконалено процес організачії навчально-пізнавальної та оздоровчої діяльності студентів з урахуванням особливостей формування культури здоров'язбереження в проиесі професійної підготовки майбутніх фахівців на засадах міждисииплінарної інтеграції.

Ключові слова: культура здоров'язбереження, педагогічні умови, міждисциплінарна інтеграція, студент, paxiвеųь.

Сучасні економічні умови розвитку України, подальший науково-технічний прогрес підвищують потреби суспільства в здорових трудових ресурсах. Стратегічними завданнями модернізації закладів вищої освіти є спрямування їх на здоров'язбереження, формування цінностей здорового способу життя, про що окреслено в Національній стратегії розвитку освіти в Україні на період до 2021 року, Загальнодержавній програмі «Здоров’я 2020: український вимір» на 2012-2020 pр. (2012 р.), Концепції розвитку освіти України на період 